\title{
Gastric Leiomyosarcoma
}

National Cancer Institute

\section{Source}

National Cancer Institute. Gastric Leiomyosarcoma. NCI Thesaurus. Code C27200.

An aggressive malignant smooth muscle neoplasm, arising from the stomach. It is characterized by a proliferation of neoplastic spindle cells. 